9 Kim HK, McKenry PC. The relationship between marriage and psychological well-being: a longitudinal analysis. J Fam Issues 2002; 23: 885-911.

10 Fergusson DM, Horwood LJ. The Christchurch Health and Development Study: review of findings on child and adolescent mental health. Aust N Z J Psychiatry 2001; 35: 287-96.

11 Fergusson DM, Horwood L, Shannon FT, Lawton JM. The Christchurch Child Development Study: a review of epidemiological findings. Paediatr Perinat Epidemiol 1989; 3: 278-301.

12 World Health Organization. Composite International Diagnostic Interview (CIDI). WHO, 1993.

13 American Psychiatric Association. Diagnostic and Statistical Manual of Mental Disorders (4th edn) (DSM-IV). APA, 1994.

14 Fergusson DM, Horwood LJ, Lynskey MT. Childhood sexual abuse and psychiatric disorder in young adulthood. II. Psychiatric outcomes of childhood sexual abuse. J Am Acad Child Adolesc Psychiatry 1996; 35 : 1365-74.

15 Reid NA, Jackson PF, Gilmore A, Croft C. Test of Scholastic Abilities. Ministry of Education, 1981.

16 Elley WB, Irving JC. Revised socio-economic index for New Zealand. New Zeal J Educ Stud 1976; 11: 25-36.

17 Fergusson DM, Horwood LJ, Lynskey MT. A longitudinal study of early childhood education and subsequent academic achievement. Aust Psychologist 1994; 29: 110-5.

18 Wechsler D. Wechsler Intelligence Scale for Children - Revised. The Psychological Corporation, 1974.
19 Quay HC, Peterson DR. Manual for the Revised Behavior Problem Checklist. H.C. Quay \& D.R. Peterson, 1987.

20 Eysenck HM, Eysenck SBG. Manual of the Eysenck Personality Inventory London University Press, 1964.

21 Cloninger CRA. Systematic method for clinical description and classification of personality variants. Arch Gen Psychiatry 1987; 44: 573-88.

22 Woodward L, Fergusson DM, Horwood LJ. Effects of single-sex and coeducational secondary schooling on children's academic achievement Aust J Educ 1999; 43: 142-56.

23 Fergusson DM, Boden JM, Horwood LJ. Exposure to childhood sexual and physical abuse and adjustment in early adulthood. Child Abuse Negl 2008; 32: $607-19$

24 Liang KY, Zeger SL. Longitudinal data analysis using generalized linear models. Biometrika 1986; 73: 13-22.

25 Zeger SL, Liang KY. Longitudinal data analysis for discrete and continuous outcomes. Biometrics 1986; 42: 121-30.

26 Lee J. Covariance adjustment of rates based on the multiple logistic regression model. J Chronic Dis 1981; 34: 415-26.

27 Grove WM, Andreasen NC. Simultaneous tests of many hypotheses in exploratory research. J Nerv Ment Dis 1982; 170: 3-8.

28 Waite LJ. Does marriage matter? Demography 1995; 32: 483-507.

29 Statistics New Zealand. Social marital status for the census usually resident population count aged 15 years and over, 2006. Statistics New Zealand, 2010 (http://www.stats.govt.nz/Census/2006CensusHomePage/classificationcounts-tables/about-people/social-marital-status.aspx).

\title{
First fictional report of folie à deux
}

\section{Daniel Martins de Barros, Geraldo Busatto Filho}

The induced psychosis, also known as folie à deux, was first described in 1887 by Lasegue \& Falret and is characterised by the transmission of delusional beliefs from a psychotic individual to a healthy individual. The article described the disorder as a syndrome occurring predominantly in women living in sheltered, isolated conditions. The syndrome was characterised by the emergence of the same psychotic symptoms in members of a family while living together, or in two very close individuals, and the transmission of psychotic symptoms from an affected individual to one or more healthy persons.

However, Machado de Assis, the Brazilian author, wrote a fictional story published 8 years before the article by Lasegue \& Falret, which contains an accurate description of folie à deux. In his story, Rafael the Angel, Assis narrates the life of a man who believed that he was the angel Rafael himself. This man lived in isolation on a farm with his daughter, who had no contact with the outside world until the age of 15 . Shortly before his death her father found her a suitor, who soon realises she had been contaminated by her father's delusions: not only did she believe that he was an angel, but defended this notion despite the disbelief of her new-found fiancé. Following the death of her father she moved from the countryside to the city and 3 months later presented no delusional beliefs.

Assis' narrative presents a picture which combines all the elements subsequently described by Lasegue \& Falret: a woman living in isolation and closely related to a psychotic family member who manifested identical psychotic symptoms and was the influence and the primary cause of her delusion. Assis went further and described the therapeutic effect of separating the individuals.

This story illustrates that, above all, literature can contribute to psychiatry by offering descriptions of conditions in remarkable detail. As noted by Sigmund Freud in Writings on Art and Literature, 'the poetic treatment of a psychiatric theme can turn out to be correct without any sacrifice of its beauty', what can be verified in this 'first case report' of folie à deux.

Daniel Martins de Barros, Institute of Psychiatry, Geraldo Busatto Filho, Institute and Department of Psychiatry, Medicine School, University of Sao Paulo. 